\title{
Taxonomic Significance of Yeast Sphaeroplast Release after Enzymic Treatment of Intact Cells
}

\author{
BY JEAN-MARIE BASTIDE, EL HADI HADIBI AND \\ MADELEINE BASTIDE \\ Department of Microbiology, Faculty of Pharmacy, Avenue Charles Flahault, \\ 34060 Montpellier, France
}

(Received 10 November 1978)

\begin{abstract}
Treatment of whole yeast cells with a mixture of a reducing agent and 1,3- $\beta$-glucanase isolated from Basidiomycete QM806 led to the production of sphaeroplasts from ascomycetes, from some fungi imperfecti, but not from basidiomycetes. Association of 1,3- $\beta$-glucanase with a second enzyme, 1,4- $\alpha$-glucanase, from Trichoderma viride, was required for sphaeroplast release from some, but not all, basidiomycetes and fungi imperfecti. The ability of yeast cells to liberate sphaeroplasts following appropriate enzymic treatment is proposed as a taxonomic criterion for differentiating basidiomycetous from ascomycetous yeasts and for classifying fungi imperfecti yeasts.
\end{abstract}

\section{INTRODUCTION}

While sexual reproduction has long been a criterion for differentiating ascomycetes from basidiomycetes, new taxonomic approaches based on the structure and chemical composition of the yeast wall have recently been reported. Kreger-van Rij \& Veenhuis (1971) established structural differences between these classes by electron microscopy. Van der Walt \& HopsuHavu (1976) used a diazonium blue B staining reaction to separate these two classes. Polysaccharides are the major constituent of the yeast wall (Northcote, 1963; Phaff, 1971). Chemical analysis of wall polysaccharides led Bartnicki-Garcia (1968) to relate them to taxonomy, and Gorin \& Spencer (1970) have used physical analysis of mannose-containing polysaccharides as an aid in classification.

Another possible taxonomic character is the sensitivity of these polysaccharides to the lytic action of various enzyme preparations. Indeed, several authors have demonstrated yeast parietal lysis by 1,3- $\beta$-glucanases (Bastide et al., 1971; Mann et al., 1972; Yamamoto et al., 1974; Rombouts \& Phaff, 1976). Furthermore, Bastide et al. (1973) showed that purified 1,3- $\beta$-glucanase associated with a reducing agent could liberate sphaeroplasts from whole Candida cells. The present communication reports the findings of a study aimed at extending this observation to a greater variety of yeast species in the hope of providing a useful means of separating ascomycetes from basidiomycetes.

\section{METHODS}

Strains. All the strains tested, representing 56 different species of yeasts belonging to the Ascomycetes or Basidiomycetes and 26 different species of fungi imperfecti yeasts, were from culture collections; most came from the Centraalbureau voor Schimmelcultures (CBS), Baarn, The Netherlands, and others were from the Institut Pasteur (IP), Paris, or from our own collection (IVP).

Strain cultivation. To minimize variations in wall constituents, only one synthetic medium, Yeast Morphology Agar (Difco B-393), was used for strain cultivation. Following three successive $48 \mathrm{~h}$ subcultures 
at appropriate temperatures, all strains were grown for $15 \mathrm{~h}$ immediately prior to enzymic treatment. Agar slants were sown with a loopful of yeast suspension.

Enzymic preparations. Basidiomycete QM806, kindly provided by Elwyn T. Reese, was grown at $26^{\circ} \mathrm{C}$ for $14 \mathrm{~d}$ in liquid medium containing glucose ( $1 \%$, w/v) as the carbon source (Reese \& Mandels, 1959). The proteins were precipitated from the culture supernatant by addition of $\left(\mathrm{NH}_{4}\right)_{2} \mathrm{SO}_{4}$ at 25 to $50 \%$ saturation. After dialysis against water and against $0.1 \mathrm{M}$-phosphate/citrate buffer, $\mathrm{pH} 6$, the enzymic extract was fractionated on a Sephadex G-100 gel column (Pharmacia K 15/30).

Trichoderma viride QM6a (United States Army Natick Laboratories, Natick, Mass., U.S.A.) was grown in a liquid medium, $\mathrm{pH} 5 \cdot 8$, containing (per litre): $5 \mathrm{~g}$ glucose, $1 \mathrm{~g}$ polypeptone (Bio-Merieux, France), $0.3 \mathrm{~g} \mathrm{~L}$-glutamic acid, $0.5 \mathrm{~g} \mathrm{KH}_{2} \mathrm{PO}_{4}, 0.3 \mathrm{~g} \mathrm{MgSO}_{4} .7 \mathrm{H}_{2} \mathrm{O}, 0.5 \mathrm{~g} \mathrm{CaCl}_{2}$ and $1 \mathrm{ml}$ trace metal solution. Following incubation at $28{ }^{\circ} \mathrm{C}$ for $10 \mathrm{~d}$, the culture supernatant was treated with 2 vol. acetone and kept for $1 \mathrm{~h}$ at $-24^{\circ} \mathrm{C}$. The precipitate was suspended in distilled water and dialysed against the same solvent. The residue was discarded and the supernatant was dialysed against a $0.02 \mathrm{M}$-acetate buffer, $\mathrm{pH} 3.9$. The enzymic preparation was then fractionated on a CM Sephadex C50 column (Pharmacia K 15/30) using a NaCl gradient in the same acetate buffer.

Enzyme assays. Enzyme fractions were assayed against the following substrates: laminarin (Koch-Light); soluble starch (Calbiochem); 1,3- $\alpha$-glucan extracted from the wall of Aspergillus niger NRRL 326 by the method of Hasegawa \& Nordin (1969); 1,6- $\beta$-glucan extracted from the wall of Penicillium aculeatum by the method of Nakamura \& Tanabe (1963). Appropriately diluted enzyme fractions were added to $2.5 \mathrm{mg}$ of each substrate suspended in $0.2 \mathrm{ml} 0.1 \mathrm{M}$-phosphate/citrate buffer, $\mathrm{pH}$. After $1 \mathrm{~h}$ incubation at $37^{\circ} \mathrm{C}$ for starch and at $50^{\circ} \mathrm{C}$ for the other substrates, reducing sugar was estimated by the Nelson-Somogyi method (Somogyi, 1952). One unit (u) of enzyme activity liberated $0.5 \mathrm{mg}$ glucose equivalent in $1 \mathrm{~h}$. Protease activity was assayed against the charcoal gelatin disc (Oxoid).

Preparation of yeast sphaeroplasts. Yeast cells from cultures grown for $15 \mathrm{~h}$ were suspended in $0.1 \mathrm{M}-$ phosphate buffer, $\mathrm{pH} 6$, at $2 \times 10^{8}$ cells $\mathrm{ml}^{-1} ; 0.2 \mathrm{ml}$ of the suspension was exposed to each lytic system. The first system was composed of an enzyme [either $0.2 \mathrm{ml}$ of Basidiomycete $1,3-\beta$-glucanase II $\left(200 \mathrm{u} \mathrm{ml}^{-1}\right)$ or $0.2 \mathrm{ml}$ of $T$. viride $1,3-\beta$-glucanase $\left.\left(40 \mathrm{u} \mathrm{ml}^{-1}\right)\right]$ associated with a reducing agent $(0.2 \mathrm{ml}$ of $0.03 \mathrm{M}$ 2-mercaptoethylamine in $0.1 \mathrm{M}$-phosphate buffer, $\mathrm{pH} 6$. The second system was composed of two T. viride enzymes [0.2 $\mathrm{ml}$ of $1,3-\beta$-glucanase $\left(40 \mathrm{u} \mathrm{ml}^{-1}\right)$ and $0.2 \mathrm{ml}$ of $1,4-\alpha$-glucanase $\left.\left(25 \mathrm{u} \mathrm{ml}^{-1}\right)\right]$. In both test systems, cells were osmotically stabilized with $0.5 \mathrm{M}-\mathrm{KCl}$ and incubated in haemolysis tubes on a reciprocal shaker at $26^{\circ} \mathrm{C}$ for $24 \mathrm{~h}$. Sphaeroplast formation was assessed by light microscopy, monitoring cell lysis on addition of water.

\section{RESULTS}

\section{Enzyme activities}

Basidiomycete QM806 produced two constitutive 1,3- $\beta$-glucanases (Fig. 1). These enzymes differed not only in molecular weight but also in their lytic activity against the wall of ascomycetous yeasts as demonstrated by sphaeroplast release: $1,3-\beta$-glucanase I was very active against laminarin and inactive against the ascomycetous wall, whereas 1,3- $\beta$-glucanase II was less active against laminarin but highly active against the ascomycetous wall.

Trichoderma viride also produced two glucanases (Fig. 2): a 1,3- $\beta$-glucanase which was very active against laminarin as well as against the ascomycetous wall, and a 1,4- $\alpha$-glucanase which alone could not liberate sphaeroplasts from either ascomycetous or basidiomycetous yeast cells. However, together the enzymes did release sphaeroplasts from basidiomycetous cells. No 1,3- $\alpha$-glucanase, $1,6-\beta$-glucanase or protease activity was detected in the enzyme preparations described above.

\section{Yeast differentiation using two lytic systems}

A total of 91 yeast species were examined in the lytic systems (Table 1). In the first lytic system, all ascomycetous yeasts tested yielded sphaeroplasts, while all basidiomycetous yeasts were resistant to this treatment, even after exposure for $48 \mathrm{~h}$. This 'all-or-none' response was not observed with the fungi imperfecti yeasts tested: four genera (Brettanomyces, Kloeckera, Trigonopsis and Candida) yielded sphaeroplasts and appeared to respond like ascomycetes, while the three other genera (Cryptococcus, Rhodotorula and Sterigmatomyces) were insensitive in this system, like basidiomycetes. 


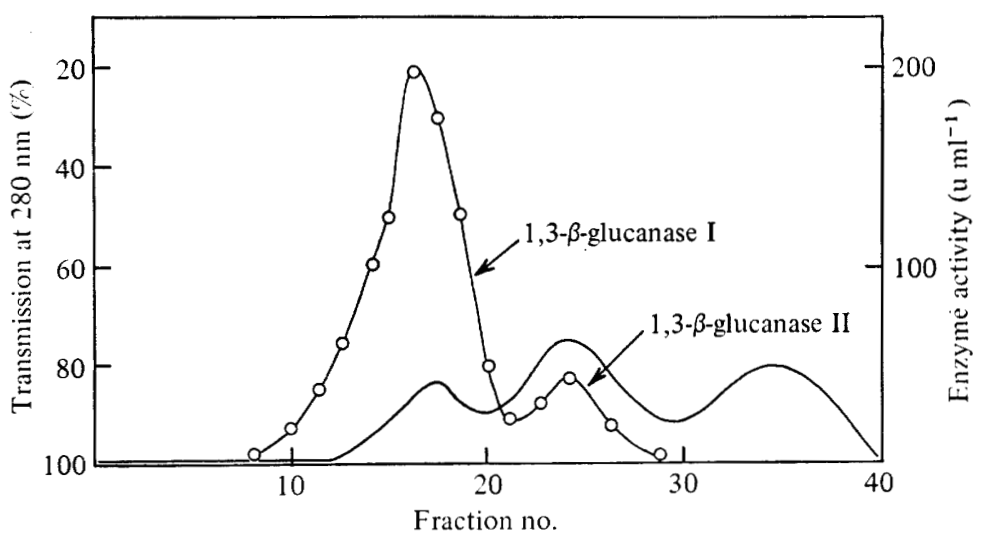

Fig. 1. Gel filtration of the enzyme preparation from Basidiomycete QM806: $2 \mathrm{mg}$ of the fraction obtained between 25 and $50 \%\left(\mathrm{NH}_{4}\right)_{2} \mathrm{SO}_{4}$ saturation were fractionated on Sephadex G-100, using $0.1 \mathrm{M}$-citrate/phosphate buffer, $\mathrm{pH}$, as eluant. Fractions of $2 \mathrm{ml}$ were collected. $\bigcirc$, Enzyme activity on laminarin; -, protein (transmission at $280 \mathrm{~nm}$ ).

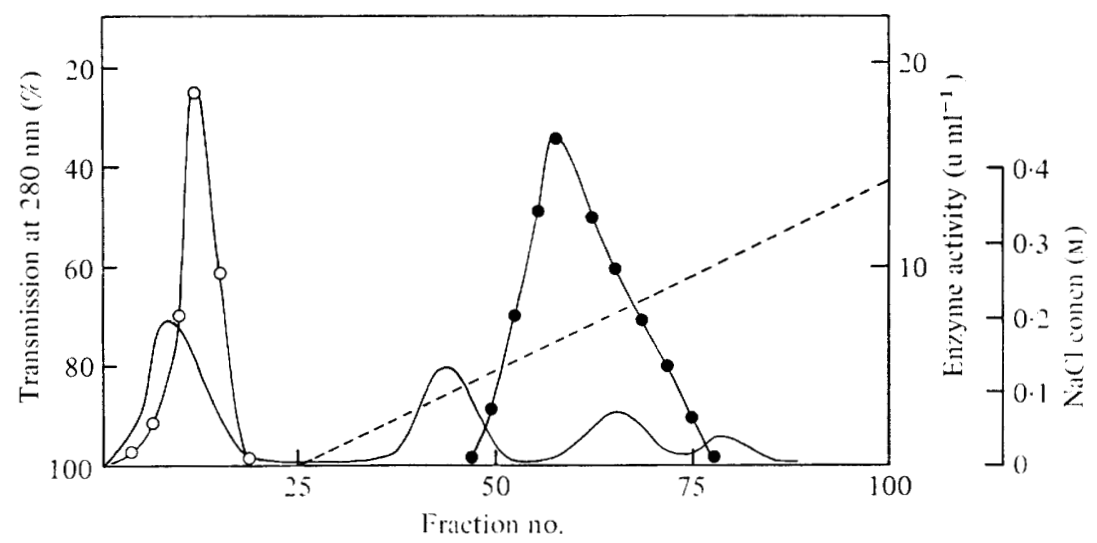

Fig. 2. CM Sephadex C50 chromatography of the enzyme preparation ( $3 \mathrm{mg}$ protein) from $T$. viride. Fractions of $2 \mathrm{ml}$ were collected. $O$, Enzyme activity on laminarin; $\boldsymbol{e}$, enzyme activity on soluble starch; - - , NaCl concentration; --, protein (transmission at $280 \mathrm{~nm}$ ).

In the second lytic system, 26 basidiomycetous species, as well as the 13 species of fungi imperfecti which responded like basidiomycetes in the first system, were examined. Among the basidiomycetes, only three species, namely Sporobolomyces roseus, Sp. gracilis and $S p$. singularis, were insensitive in this system, while within the fungi imperfecti all Cryptococcus species were sensitive and all Rhodotorula and Sterigmatomyces species were resistant.

\section{DISCUSSION}

Structural studies on walls of ascomycetous yeasts have revealed the presence around the glucan layer of an envelope composed of a mannan-protein complex rich in disulphide bridges (Lampen, 1968; Kidby \& Davies, 1970). Our results seem to be in agreement with this finding since the addition of a reducing agent was required for maximum sphaeroplast release from ascomycetous yeasts.

While very little is known about the wall structure of basidiomycetous yeasts, the presence of a starch-like substance in the growth medium of some Bullera and Leucosporidium species has been reported by Phaff (1970) and Fell et al. (1969). Our results suggest that, except for 
Table 1. Yeast sphaeroplast release after enzymic treatment*

$\begin{array}{cc}1,3-\beta- & 1,3-\beta- \\ \text { Glucanase } & \text { Glucanase } \\ \text { and } & \text { and } \\ \text { reducing } & 1,4-\alpha- \\ \text { agent } & \text { glucanase }\end{array}$

Ascomycetes

Dipodascus agregatus

Dip. albidus

Endomyces lactis

E. geotrichum

Nematospora coryli

Nadsonia elongata

Saccharomycodes ludwigii

Sacch. ludwigii var. bisporus

Strain no.

agent

$1,4-\alpha-$

Species

CBS 17553

CBS 15257

CBS 17853

IVP 603

CBS 2608

CBS $114 \mathrm{~T}$

CBS 821

Hanseniaspora apuliensis

Hans, valbyensis

CBS 2624

CBS 1972

IVP 399

Lipomyces lipofer

L. starkeyi

Saccharomyces carlsbergensis

CBS 944

IVP 405

IVP 386

S. cerevisiae

S. ellipsoideus

IVP 387

S. fragilis

S. rosei

IVP 389

IVP 390

IVP 391

S. uvarum

IVP 599

Kluyveromyces africanus

$K$. polysporus

Endomycopsis bispora

End. capsularis

End. javanensis

End. chodati

Pichia fermentans

P. bovis

$P$. membranaefaciens

P. fibuligera

CBS 2517

CBS 2163

CBS 5515

CBS 2519

CBS 2555

IVP 601

CBS 187

IVP 400

CBS 107

CBS 2521

Hansenula anomala

H. angusta

$H$. californica

$H$. beckii

Citeromyces matritensis

CBS 112

CBS 1976

CBS 5760

CBS 1890

CBS 2764

Debaryomyces japonicus

Deb. kloeckeri

Deb. kloeckeri

Deb. hansenii

Metschnikowia pulcherrima

Dekkera intermedia

CBS 2334

CBS 5770

CBS 770

CBS 767

IVP 604

IVP 598

Basidiomycetes

Leucosporidium antarcticum

CBS 5942

Leu. nivale

Leu. gelidum

Leu. frigidum

Leu. scottii

Leu. capsuligenum

Sporobolomyces salmonicolor

Sp. odorus

Sp. holsaticus

Sp. albidus

Sp. gracilis

Sp. roseus

CBS 5266

CBS 5272

CBS 5270

CBS 614

CBS 1906

CBS 490

CBS 2636

CBS 1522

CBS 2839

CBS 71

CBS 1486

+
+
+
+
+
+
+
+
+
+
+
+
+
+
+
+
+
+
+
+
+
+
+
+
+
+
+
+
+

$\begin{array}{ll}- & + \\ - & + \\ - & + \\ - & + \\ - & + \\ - & + \\ - & + \\ - & + \\ - & + \\ - & + \\ - & +\end{array}$


Table 1 (cont.)

Sp. hispanicus
Sp. singularis
Bullera alba
B. dendrophila
B. tsugae
B. piricola

Rhodosporidium diobovatum Rhodosp. toruloides

Rhodosp. sphaerocarpum

Rhodosp. capitatum

Rhodosp. infirmominiatum

Rhodosp. malvinellum

Filobasidium capsuligenum

Sporidiobolus johnsonii

\section{Fungi Imperfecti}

Brettanomyces anomalus

Br. bruxellensis

Kloeckera apiculata

Kl. africana

Kl. javanica

Trigonopsis variabilis

Candida albicans

C. krusei

C. macedoniensis

C. pelliculosa

C. pseudotropicalis

C. tropicalis

C. utilis

Cryptococcus albidus var. diffluens

Cr. ceraneus

Cr. flavus

Cr. gastricus

Cr. laurentii

Cr. neoformans

Rhodotorula aurantiaca

Rh. glutinis

Rh. lactosa

Rh. marina

$R h$. pallida

Sterigmatomyces indicus

St. polyborus

$\begin{array}{lcc} & 1,3-\beta \text { - } & 1,3-\beta- \\ & \begin{array}{c}\text { Glucanase } \\ \text { and } \\ \text { reducing }\end{array} & \begin{array}{c}\text { Glucanase } \\ \text { and }\end{array} \\ \text { agent } & \text { glucanase } \\ \text { Strain no. } & \text { agent } & \text { glu } \\ \text { CBS 2873 } & - & + \\ \text { CBS 5109 } & - & - \\ \text { CBS 501 } & - & + \\ \text { CES 6074 } & - & + \\ \text { CBS 5038 } & - & + \\ \text { CBS 6754 } & - & + \\ \text { (Stadelman 141 L) } & \\ \text { CBS 6085 } & - & + \\ \text { CBS 14 } & - & + \\ \text { CBS 5939 } & - & + \\ \text { CBS 6358 } & - & + \\ \text { CBS 323 } & - & + \\ \text { CBS 6082 } & - & + \\ \text { CBS 1906 } & - & + \\ \text { CBS 522-50 } & - & + \\ & & \\ \text { CBS 77 } & + & \pm \\ \text { CBS 72 } & + & \pm \\ \text { IVP 408 } & + & \pm \\ \text { CBS 277 } & + & \pm \\ \text { CBS 282 } & + & \pm \\ \text { CBS 1040 } & + & \pm \\ \text { IP 628 } & + & \pm \\ \text { IP 208 } & + & \pm \\ \text { CBS 600 } & + & \pm \\ \text { IP 606 } & + & \pm \\ \text { IP 513 } & + & \pm \\ \text { IP 857 } & + & \pm \\ \text { CBS 621 } & + & \pm \\ \text { CBS 160 } & - & + \\ \text { CBS 6644 } & - & + \\ \text { CBS 331 } & - & + \\ \text { CBS 2288 } & - & + \\ \text { CBS 139 } & - & + \\ \text { CBS 132 } & - & + \\ \text { CBS 317 } & - & - \\ \text { CBS 124 T } & - & - \\ \text { CBS 5826 } & - & - \\ \text { CBS 2365 } & - & - \\ \text { CBS 320 } & - & - \\ \text { CBS 5628 } & - & - \\ \text { CBS 6072 } & - & - \\ \text { of sphaeroplasts; } & - \text { no sphaeroplasts formed. } \\ & & \end{array}$

$*+$, Release of sphaeroplasts; \pm weak release of sphaeroplasts;,- no sphaeroplasts formed.

the three species of Sporobolomyces, all other basidiomycetous yeasts as well as the species of Cryptococcus tested possess 1,4- $\alpha$-glucan associated with 1,3- $\beta$-glucan in their walls.

Using the wall lytic systems described here, we have not only been able to separate ascomycetous from basidiomycetous yeasts but have also been able to place some of the fungi imperfecti in one or other of these two groups. This latter finding is consistent with the results of other investigations. Kreger-van Rij \& Veenhuis (1971) showed the presence of a typical basidiomycetous lamellar structure in the walls of Cryptococcus diffluens, Rhodotorula glutinis and Sterigmatomyces halophilus. Van der Walt \& Hopsu-Havu (1976) showed that 
Cryptococcus albidus, Cr. laurentii and Cr. neoformans as well as Rhodotorula minuta, $R h$. rubra, Sterigmatomyces elviae and $S t$. polyborus reacted like basidiomycetes to diazonium blue staining. Earlier studies of DNA base content of fungi imperfecti yeasts revealed that, having $<50 \% \mathrm{G}+\mathrm{C}$ content, Candida species, Kloeckera apiculata, Brettanomyces bruxellensis and Trigonopsis variabilis could be grouped with the ascomycetes, while Rhodotorula glutinis, Rh. rubra and Sterigmatomyces elviae could be grouped with the basidiomycetes which have $>50 \% \mathrm{G}+\mathrm{C}$ content (Nakase \& Komagata, 1968, 1971; Meyer \& Phaff, 1969). By DNA hybridization studies, Stenderup \& Leth Bak (1969) identified Kluyveromyces fragilis as the perfect form of Candida pseudotropicalis, and indeed, this species grouped with the ascomycetes in our tests. Furthermore, Kwon-Chung (1975) and Kwon-Chung \& Popkin (1976) identified the basidiomycete Filobasidiella neoformans as the perfect form of Cryptococcus neoformans and, because of the similarity in their extracellular polysaccharides, Slodki et al. (1966) suggested that Tremella and Cryptococcus might be related.

While the selective sensitivity to the first lytic system developed provides a convenient means for separating the two major classes, the separation of species within the basidiomycetes can be achieved by the use of the second lytic system. So far, Bullera and Sporobolomyces have been distinguished only by their ballistospore forms; our results suggest that five of the eight species of Sporobolomyces are related to Bullera and that the three species which were not sensitive to the second lytic system are true Sporobolomyces (Sp. roseus, $S p$. gracilis and $S p$. singularis). Using the second lytic system we have also been able to separate the genus Cryptococcus from the genus Rhodotorula. These two fungi imperfecti have been shown by chemical analysis to differ in the nature of their wall polysaccharides (Elinov et al., 1974). Our results strongly suggest that sphaeroplast release by means of the two lytic systems investigated could be useful in improving the classification of fungi imperfecti yeasts.

We thank Drs A. and S. L. Salhi for helpful discussion during the preparation of this manuscript. The technical assistance of Miss S. Jouvert is greatly appreciated. We also thank the United States Army Natick Laboratories and Dr E. T. Reese for generously supplying the micro-organisms.

\section{REFERENCES}

BartNicki-Garcia, S. (1968). Cell wall chemistry, morphogenesis and taxonomy of fungi. Annual Review of Microbiology 22, 87-108.

Bastide, J. M., Trave, P. \& Bastide, M. (1971). Étude de la paroi cellulaire de Candida macedoniensis: formation de protoplastes. Annales de l'Institut Pasteur 121, 311-324.

Bastide, M., Trave, P. \& Bastide, J. M. (1973). L'hétérogénéité de structure de la paroi dans le genre Candida a-t-elle une incidence taxonomique? Annales de Microbiologie (Institut Pasteur) 124A, 359-373.

Elinov, N. P., Vitovskaya, G. A., Kaloshin, V. G. \& Kolotinskaya, T. M. (1974). Structural polysaccharides of some species of Rhodotorula and Cryptococcus, Biokhimiya 39, 787-792.

Fell, J. W., Stazell, A. C., Hưnter, I. L. \& Phaff, H. J. (1969). Leucosporidium gen.n., the heterobasidiomycetous stage of several yeasts of the genus Candida. Antonie van Leeuwenhoek 35, 433462.

Gorin, P. A. J. \& Spencer, J. F. T. (1970). Proton magnetic resonance spectroscopy. An aid in identification and chemotaxonomy of yeasts. Advances in Applied Microbiology 12, 25-89.
Hasegawa, S. \& Nordin, J. (1969). Enzymes that hydrolyse fungal cell wall polysaccharides. Journal of Biological Chemistry 244, 5460-5470.

KIDBY, D. K. \& DAvies, R. (1970). Invertase and disulphide bridges in the yeast wall. Journal of General Microbiology 61, 327-333.

KREGer-VAN RiJ, N. J. W. \& Veenhuis, N. (1971). A comparative study of the cell wall structure of basidiomycetous and related yeasts. Journal of General Microbiology 68, 87-95.

Kwon-Chung, K. J. (1975). Description of a new genus, Filobasidiella, the perfect state of Cryptococcus neoformans. Mycologia 67, 1197-1200.

Kwon-Chung, K. J. \& Popkin, T. J. (1976). Ultrastructure of septal complex in Filobasidiella neoformans (Cryptococcus neoformans). Journal of Bacteriology 126, 524-528.

LAMPEN, J. O. (1968). External enzymes of yeast: their nature and formation. Antonie van Leeuwenhoek 34, 1-18.

ManN, J. W., Heintz, C. E. \& Macmillan, J. D. (1972). Yeast sphaeroplasts formed by cell wall degrading enzymes from Oerskovia sp. Journal of Bacteriology 111, 821-824.

Meyer, S. A. \& Phaff, H. J. (1969). Deoxyribo- 
nucleic acid base composition in yeasts. Journal of Bacteriology 97, 52-56.

Nakamura, N. \& TANABE, O. (1963). Studies on an enzyme capable of splitting $\beta$-D- $(1,6)$-glucosidic linkage. Agricultural and Biological Chemistry 27, 80-87.

NAKase, T. \& Komagata, K. (1968). Taxonomic significance of base composition of yeast DNA. Journal of General and Applied Microbiology 14, 345-357.

Nakase, T. \& Komagata, K. (1971). DNA base composition of some species of yeasts and yeastlike fungi. Journal of General and Applied Microbiology 17, 363-369.

NoRTHCOTE, D. H. (1963). The structure and organisation of the polysaccharides of yeast. Pure and Applied Chemistry 7, 669-675.

Phaff, H. J. (1970). Discussion of the yeast-like genera belonging to the Sporobolomycetaceae. In The Yeasts. A Taxonomic Study, 2nd edn, pp. 815862. Edited by J. Lodder. Amsterdam: North Holland Publishing Co.

Phaff, H. J. (1971). Structure and biosynthesis of the yeast cell envelope. In The Yeasts, vol. 2, pp. 135-210. Edited by A. H. Rose \& J.S. Harrison. London \& New York: Academic Press.
Reese, E. T. \& MANDEls, M. (1959). $\beta$-(1-3)-Glucanases in fungi. Canadian Journal of Microbiology 5, 173-185.

Rombouts, F. M. \& Phaff, H. J. (1976). Lysis of yeast cell walls. Lytic $\beta$-(1,3)-glucanases from Bacillus circulans WL-12. European Journal of Biochemistry 63, 121-103.

Slodki, M. E., Wickerman, L. J. \& Bandoni, R. J. (1966). Extracellular heteropolysaccharides from Cryptococcus and Tremella: a possible taxonomic relationship. Canadian Journal of Microbiology 12, $489-494$.

Somogyi, M. (1952). Notes on sugar determination. Journal of Biological Chemistry 195, 19-23.

Stenderup, A. \& LeTH BAK, A. (1969). DNA homology among perfect and imperfect yeasts. Antonie van Leeuwenhoek 35, suppl. A 13.

VAN Der Walt, J. P., \& Hopsu-HAVU, U. K. (1976). A colour reaction for the differentiation of ascomycetous and basidiomycetous yeasts. Antonie van Leeuwenhoek 42, 157-163.

Yamamoto, S., Kobayashi, R. \& NagasaKi, S. (1974). Physicochemical, chemical and enzymatic properties of a crystalline yeast cell lytic enzyme from a Rhizopus mold. Agricultural and Biological Chemistry 38, 1563-1573. 